\title{
Organization of genes for tetrapyrrole biosynthesis in Gram-positive bacteria
}

\author{
Per Johansson and Lars Hederstedt
}

Department of

Microbiology, Lund

University, Solvegatan 12

S-22362 Lund, Sweden

\author{
Author for correspondence: Lars Hederstedt. Tel: +46 46 2228622. Fax: +46 46157839. \\ e-mail: Lars.Hederstedt@mikrbiol.lu.se
}

\begin{abstract}
Clusters of genes encoding enzymes for tetrapyrrole biosynthesis were cloned from Bacillus sphaericus, Bacillus stearothermophilus, Brevibacillus brevis and Paenibacillus macerans. The sequences of all hemX genes found, and of a $6.3 \mathrm{kbp}$ hem gene cluster from P. macerans, were determined. The structure of the hem gene clusters was compared to that of other Gram-positive bacteria. The Bacillus and Brevibacillus species have a conserved organization of the genes hemAXCDBL, required for biosynthesis of uroporphyrinogen III (Urolli) from glutamyl-tRNA. In P. macerans, the hem genes for Urolll synthesis are also closely linked but their organization is different: there is no hemX gene and the gene cluster also contains genes, cys $G^{B}$ and $c y s G^{A}-$ hemD, encoding the enzymes required for synthesis of sirohaem from Urolli. Bacillus subtilis contains genes for three proteins, NasF, YInD and YInF, with sequence similarity to Escherichia coli CysG, which is a multi-functional protein catalysing sirohaem synthesis from Urolll. It is shown that YInF is required for sirohaem synthesis and probably catalyses the precorrin- 2 to sirohaem conversion. YInD probably catalyses precorrin-2 synthesis from UrollI and NasF seems to be specific for nitrite reduction.
\end{abstract}

Keywords: sirohaem, haem synthesis, Bacillus, tetrapyrrole synthesis, hem genes

\section{INTRODUCTION}

Biosynthesis of tetrapyrroles from the common intermediate 5-aminolaevulinic acid (ALA) follows a pathway universal to all living organisms (Fig. 1). There are, however, two separate biosynthetic pathways leading to ALA (for a review see Avissar \& Moberg, 1995). Uroporphyrinogen III (UroIII) is the first cyclic tetrapyrrole intermediate in the pathway and is a precursor both to oxidized tetrapyrroles, such as haem and chlorophylls, and to reduced tetrapyrroles, such as sirohaem, vitamin $\mathrm{B}_{12}$ and haem $d_{1}$.

In the Gram-positive bacteria Bacillus subtilis, Clostridium josui, Mycobacterium tuberculosis and Staphylococcus aureus, the genes for enzymes catalysing

\footnotetext{
Abbreviations: ALA, 5-aminolaevulinic acid; BGSC, Bacillus Genetic Stock Center; TBAB, Tryptose Blood Agar Base; Urolll, uroporphyrinogen III.

The GenBank accession numbers for the sequences determined in this work are AF064058 (B. stearothermophilus hemX), AF064059 (Br. brevis hemX), AF064060 (B. sphaericus hem $X$ ) and AF064061 ( $P$. macerans hemA cys $G^{B}$ hem $\left(\right.$ cys $G^{\mathrm{A}}$-hemD).
}

the biosynthesis of UroIII are organized in operons (Hansson et al., 1991; Fujino et al., 1995; Cole et al., 1998; Kafala \& Sasarman, 1997). The gene order in the hem operons from these species is the same, but there are some differences in the genes present. B. subtilis and $S$. aureus have a bemAXCDBL operon, encoding the enzymes for UrollI synthesis from glutamyl-tRNA (Fig. 1). The hem $X$ gene is not essential for haem synthesis in B. subtilis (Schröder et al., 1994). HemX is a polytopic membrane protein which by an unknown mechanism down-regulates the level of HemA (Schröder et al., 1994). It is notable that Escherichia coli does not contain a hemX gene (Blattner et al., 1997).

The hemE, hemH and hem $Y$ genes in Gram-positive bacteria are required for protohaem IX synthesis from UroIII and tend to be clustered, e.g. in B. subtilis (Hansson \& Hederstedt, 1992), Mycobacterium (GenBank accession no. L01536; Cole et al., 1998), Propionibacterium freudenreichii (Hashimoto et al., 1997) and Deinococcus radiodurans (sequence data obtained through early release from The Institute for Genomic Research at www.tigr.org).

The compact organization of hem genes in Gram- 


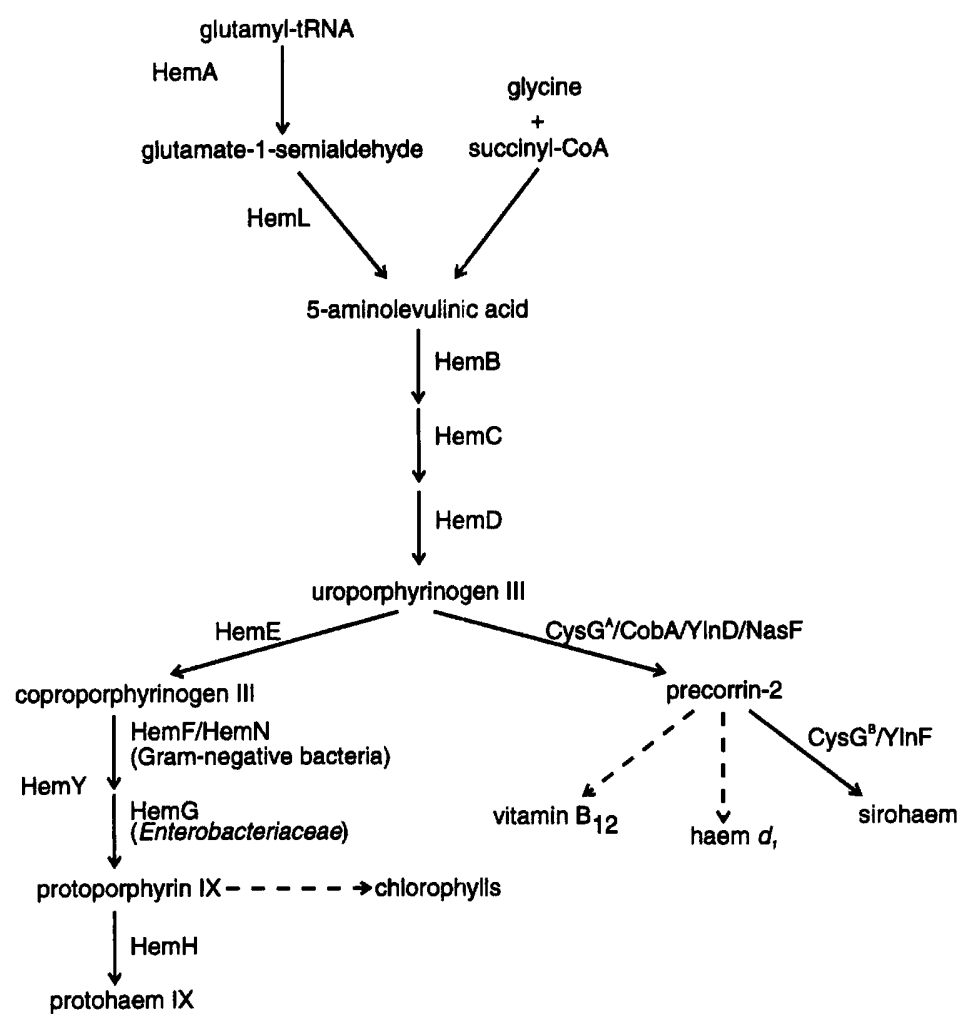

Fig. 1. Overview of tetrapyrrole biosynthesis, with gene products indicated. In animals, fungi and proteobacteria of the $\alpha$-subdivision, 5-aminolaevulinic acid (ALA) is synthesized from succinyl-coenzyme $A$ and glycine. In plants, most bacteria and archaea, ALA is synthesized from glutamyl-tRNA by the action of glutamyl-tRNA reductase (HemA) and glutamate-1semialdehyde aminotransferase (HemL). Uroporphyrinogen III (UrollI) is formed from ALA in three steps, catalysed by ALA dehydratase (HemB), porphobilinogen deaminase (HemC) and Urolll synthase (HemD), respectively. Synthesis of sirohaem, vitamin $B_{12}$ and haem $d_{1}$ involves an S-adenosylmethionine-dependent methylation of Uroll to form precorrin-2, which is catalysed by Urolll methyltransferase. Oxidation of precorrin-2 to sirohydrochlorin and chelation of sirohydrochlorin with iron results in sirohaem. Two of the enzymes for the synthesis of protohaem IX from Urolll are common to all organisms: Urolll decarboxylase (HemE) and ferrochelatase (HemH). Bacteria of the family Enterobacteriaceae have an aerobic and an anaerobic coproporphyrinogen III oxidase, HemF and HemN respectively, and protoporphyrinogen IX oxidase, HemG. Gram-positve bacteria and some Gram-negative bacteria have a HemY protoporphyrinogen IX oxidase but do not contain the HemF/HemN coproporphyrinogen III oxidase. The B. subtilis HemY protein can oxidize coproporphyrinogen III to coproporphyrin III and protoporphyrinogen IX to protopophyrin IX (Dailey et al., 1994; Hansson \& Hederstedt, 1994) but does not resemble HemG (Hansson et al., 1997). A third group of Gram-negative bacteria have HemF/HemN but do not contain either HemY or HemG.

positive bacteria is probably important for regulation. It may also be of evolutionary significance and could be related to the metabolism of the different bacteria. The aim of the present work was to better understand the organization of hem genes and to analyse the occurrence and sequence of the bemX gene in Gram-positive bacteria. hem gene clusters from Bacillus species, Brevibacillus brevis and Paenibacillus macerans were cloned and the gene organization analysed. The bacteria chosen represent different phenotypes ranging from strictly aerobic to facultatively anaerobic and also include a thermophilic species (Bacillus stearothermophilus). From this work a role of the B. subtilis $Y \ln F$ protein in sirohaem synthesis was also identified.

\section{METHODS}

Bacterial strains and plasmids. These are listed in Table 1.
Media and growth of bacteria. B. subtilis strains, P. macerans (previously Bacillus macerans: Ash et al., 1993) and B. sphaericus were grown on Tryptose Blood Agar Base (TBAB; Difco), in LB medium (Sambrook et al., 1989) or in Spizizen's minimal medium (Spizizen, 1958) with required amino acids added at $20 \mathrm{mg} \mathrm{l}^{-1}$. E. coli strains were grown on TBAB, in LB medium or in M9 minimal medium (Sambrook et al., 1989). B. stearothermophilus was grown on LA plates or in LB medium modified by exclusion of $\mathrm{NaCl}$. Br. brevis (previously Bacillus brevis: Shida et al., 1996) was grown on TBAB or in Todd-Hewitt Broth. B. stearothermophilus was grown at $55^{\circ} \mathrm{C}, \mathrm{Br}$. brevis and B. sphaericus at $30^{\circ} \mathrm{C}$, and all other bacteria at $37^{\circ} \mathrm{C}$. The following antibiotics were used: ampicillin ( $\left.75 \mathrm{mg} \mathrm{l}^{-1}\right)$, chloramphenicol (E. coli, $12.5 \mathrm{mg} \mathrm{l}^{-1}$; $B$. subtilis $\left.5 \mathrm{mg} \mathrm{l}^{-1}\right)$, erythromycin $\left(3 \mathrm{mg} \mathrm{l}^{-1}\right)$, kanamycin (20 $\left.\mathrm{mg} \mathrm{l}^{-1}\right)$. Media containing haemin (liquid media, $0.5 \mathrm{mg} \mathrm{l}^{-1}$; plates, $2.5 \mathrm{mg} \mathrm{l}^{-1}$ ) were supplemented with cysteine $\left(20 \mathrm{mg} \mathrm{l}^{-1}\right)$ and $0.5 \%(\mathrm{w} / \mathrm{v})$ bovine serum albumin fraction $\mathrm{V}$ (Sigma). Haemin stock solutions were prepared as described previously (Petricek et al., 1990). 
Complementation of $B$. subtilis and $E$. coli mutations. Complementation of the ALA requirement of the $B$. subtilis strain KA11 was assayed on Spizizen's minimal medium plates. The other $B$. subtilis and $E$. coli hem mutants were tested for complementation on TBAB plates. B. subtilis $y \ln F$ and nasF mutants were tested for complementation on Spizizen's minimal medium plates with nitrate as nitrogen source. E. coli cys $G$ mutants were tested for complementation on M9 minimal medium plates. Chromosomal DNA isolated from $B r$. brevis, B. stearothermophilus and P. macerans was partially cleaved with Sau3A. DNA from B. sphaericus was partially cleaved with the isoschizomer $M b o l$ since it was resistant to cleavage by Sau3A (indicating that the $C$ residue of the GATC recognition sequence is methylated in $B$. sphaericus). The cleaved DNA was size-fractionated and fragments of $5-10 \mathrm{kbp}$ were ligated to BamHI-cleaved $B$. subtilis $-E$. coli shuttle plasmids pHP13 or pHB201. pHB201 has a $\sigma^{A}$-type promoter in front of the cloning cassette to facilitate expression of cloned genes in B. subtilis (Haima et al., 1990). B. subtilis strains were transformed with the ligation mixtures and haem prototrophs were selected. The colonies obtained were transferred to plates containing chloramphenicol to confirm that they carried the respective plasmids. Plasmid DNA was then extracted from the transformants and used in retransformation of the B. subtilis hem mutants. Finally, the cloned fragments were used in Southern blot analysis to verify that they represented continuous segments of the chromosome of the respective bacterial species.

Construction of $B$. subtilis $168 \Delta$ YlnF. The last part of $B$. subtilis $y \ln F(601 \mathrm{bp}$ ) was amplified by PCR, using primers $\mathrm{Y} \ln 3.5$ and $\mathrm{Y} \ln 4$ (Table 2), and cloned in pBluescript II $\mathrm{KS}(-)$ giving plasmid pYLN2. The cat gene from $\mathrm{pHV} 32$ was inserted in pYLN2 giving plasmid pYLN3. The first part of $B$. subtilis $y \ln F(277 \mathrm{bp}$ ) was amplified by PCR, using primers YLN10 and YLN20, and cloned in pYLN3 giving plasmid pYLN30. By transforming B. subtilis 168 with pYLN30 and selecting for $\mathrm{Cm}^{\mathrm{r}}$, an internal region of the $y \ln F$ gene (nucleotides 1635115-1635381) was replaced with the cat gene, as confirmed by Southern blot analysis.

DNA techniques. Plasmids were propagated in E. coli XL-1 Blue. Large-scale preparations of plasmid DNA were carried out as described by Ish-Horowicz \& Burke (1981). Small-scale preparations of plasmid DNA were performed by the boiling method (Sambrook et al., 1989) or by using the Quantum purification system (Bio-Rad). Plasmid DNA was sequenced using the Sequenase version $2.0 \mathrm{kit}$ and $\left[{ }^{35} \mathrm{~S}\right] \mathrm{dATP} \alpha \mathrm{S}$ (Amersham). DNA amplification was achieved by PCR using Taq polymerase (Boehringer Mannheim). Chromosomal DNA was prepared as described by Marmur (1961). Chromosomal DNA fragments were size-fractionated by sucrose gradient centrifugation. Southern blot analysis of chromosomal DNA was performed using a random priming kit and $\left[\alpha-{ }^{32} \mathrm{P}\right] \mathrm{dCTP}$ (Amersham). The programs used for sequence analysis were part of the Wisconsin Package Version 8.1 (Genetics Computer Group, Madison, WI, USA).

Other methods. SDS-PAGE was performed according to Neville (1971). Western blotting was performed according to Towbin et al. (1979) using a semi-dry electroblotter (Ancos) and Immobilon $P$ filters. The antiserum against $B$. subtilis HemA was described by Schröder et al. (1994). Goat antirabbit IgG conjugated to alkaline phosphatase (Clontech) was used as secondary antibody. Protein concentrations were determined using the bicinchoninic acid protein assay (Pierce) with bovine serum albumin as standard.

\section{RESULTS AND DISCUSSION}

\section{Cloning of hem genes}

The B. subtilis strains $1 \mathrm{~A} 589$ (hemB1) and $1 \mathrm{~A} 590$ (hem C33) have a strict growth requirement for external haem and give essentially no background growth when $10^{7}-10^{8}$ cells are spread on TBAB plates (Anderson \& Ivánovics, 1967). Since the hemB and hem $C$ genes are well conserved in many bacteria (Rhie et al. 1996; Kafala \& Sasarman, 1997), the above B. subtilis mutant strains were used to isolate hem genes from other bacteria by complementation as described in Methods.

DNA fragments which complemented B. subtilis hemB1 and hemC33 mutations were obtained from $B$. sphaericus and $P$. macerans. Only hemB1-complementing fragments were found for $\mathrm{Br}$. brevis and $B$. stearothermophilus in a primary screen. However, when the hemB1-complementing plasmids were isolated and used to transform the hem C33 mutant to chloramphenicol resistance, the plasmids could then complement the hemC33 mutation (Table 3). It appears that bem $C$ from these species is either not efficiently expressed in B. subtilis or is, for other reasons, not fully functional.

A $P$. macerans chromosomal DNA fragment that complemented B. subtilis bem $H$ (strain $3 \mathrm{G} 18 \Delta 8$ ) and a $B$. sphaericus DNA fragment that complemented $B$. subtilis hemA (strain KA11) were also isolated. Use of the various fragments cloned by complementation as probes permitted the isolation of additional fragments which cover a larger portion of the respective chromosomes.

\section{Organization of hem genes for synthesis of Urolll from glutamyl-tRNA in Br. brevis, B. sphaericus and B. stearothermophilus}

A hem $A X C D B L$ gene cluster with the same compact organization as in B. subtilis was found in Br. brevis, $B$. sphaericus and B. stearothermophilus as determined by sequence analysis and complementation experiments (Fig. 2, Table 3). The spacing between the proposed stop codon of one gene and the proposed start codon of the next gene ranged from $210 \mathrm{bp}$ (between hem $A$ and hem $X$ in B. sphaericus) to $12 \mathrm{bp}$ (for several genes).

Deletion of bemX in B. subtilis causes the steady-state amount of HemA protein to increase (Schröder et al., 1994). No other phenotype has been observed in such mutants. Expression of hemX from $\mathrm{Br}$. brevis, on plasmid pXBRE411, or B. subtilis hemX, on plasmid pHEMX403, in the $B$. subtilis HemX deletion mutant $3 \mathrm{G} 18 \Delta \mathrm{HemX}$ in both cases led to a decrease in the amount of HemA protein, as determined by Western blot analysis (data not shown). This demonstrated that the $B$. subtilis and $B r$. brevis HemX proteins are functionally interchangeable. The HemX proteins from $B$. subtilis, B. stearothermophilus, Br. brevis and $B$. sphaericus are of the same size (272-276 residues) and show about $22 \%$ sequence identity across the entire 
Table 1. Bacterial strains and plasmids

\begin{tabular}{|c|c|c|}
\hline Strain or plasmid & Genotype or relevant description & Source \\
\hline \multicolumn{3}{|l|}{ Strains } \\
\hline B. subtilis $1 \mathrm{~A} 589$ & $\operatorname{trp} C 2$ hemB1 & BGSC \\
\hline B. subtilis $1 \mathrm{~A} 590$ & $\operatorname{trp} C 2$ hem $C 33$ & BGSC \\
\hline B. subtilis $1 \mathrm{~A} 591$ & $\operatorname{trp} C 2$ hemD11 & BGSC \\
\hline B. subtilis $3 \mathrm{G} 18 \Delta \mathrm{HemX}$ & ade met trpC2 $\Delta$ hem $\mathrm{X}::$ ble & Schröder et al. (1994) \\
\hline B. subtilis KA11 & ade met trp $C 2$ hem $A 20$ & Holmgren et al. (1979) \\
\hline B. subtilis $3 \mathrm{G} 18 \Delta 7$ & ade met trpC2 $\triangle$ hemEHY::ble & $\begin{array}{l}\text { Hansson \& Hederstedt } \\
\text { (1992) }\end{array}$ \\
\hline B. subtilis $3 \mathrm{G} 18 \Delta 8$ & ade met trpC2 $\Delta$ hemH $::$ ble & $\begin{array}{l}\text { Hansson \& Hederstedt } \\
\text { (1994) }\end{array}$ \\
\hline B. subtilis 168 & $\operatorname{trp} C 2$ & BGSC \\
\hline B. subtilis $168 \Delta \mathrm{Y} \operatorname{lnF}$ & $\operatorname{trp} C 2 \Delta y \ln F:: c a t$ & This study \\
\hline B. subtilis LAB1926 & trpC2 pheA1 nasEF:: pML16 & Ogawa et al. (1995) \\
\hline Br. brevis ATCC 8246 & & BGSC \\
\hline B. sphaericus ATCC 33203 & & BGSC \\
\hline B. stearothermophilus 9A14 & $t h r-1$ & BGSC \\
\hline P. macerans DSM 24 & & Schirawski \& Unden (1995) \\
\hline E. coli XL-1 Blue & $\begin{array}{l}\text { supE44 hsdR17 recA1 endA1 gyrA46 thi relA1 lac } \\
\mathrm{F}^{\prime}\left[\text { pro } A B^{+} \text {lacl }^{\mathrm{q}} \text { lacZ } \mathrm{ZM} 15 \mathrm{Tn} 10\left(\mathrm{Tet}^{\mathrm{r}}\right\rangle\right]\end{array}$ & Stratagene \\
\hline E. coli $302 \Delta \mathrm{a}$ & cys $G$ & Griffiths \& Cole (1987) \\
\hline E. coli AN344 & bemA pro leu & MacGregor (1976) \\
\hline E. coli SASZ31 & hisG1 rpsL9 xylA7 hemD31 mobA2 argH1 $\Delta$ thi-1 met & Chartrand et al. (1979) \\
\hline \multicolumn{3}{|l|}{ Plasmids } \\
\hline pBluescript II KS/SK(-) & $A_{p}^{r} l a c Z^{\prime}$ & Stratagene \\
\hline pUC19 & $\mathrm{Ap}^{r}$ & Yanisch-Perron et al. (1985) \\
\hline pHP13 & $\mathrm{Cm}^{\mathrm{r}} \mathrm{Em}^{\mathrm{r}}$ & Haima et al. (1987) \\
\hline pHB201 & $\mathrm{Cm}^{r} \mathrm{Em}^{\mathrm{r}}$ & $\begin{array}{l}\text { S. Bron, University of } \\
\text { Groningen }\end{array}$ \\
\hline pACYC177 & $\mathrm{Ap}^{r} \mathrm{Km}^{\mathrm{r}}$ & Chang \& Cohen (1978) \\
\hline $\mathrm{pHV} 32$ & $A p^{r} \mathrm{Cm}^{r} \mathrm{Tc}^{\mathrm{r}}$ & Niaudet et al. (1982) \\
\hline pLUM403 & $\begin{array}{l}296 \text { bp HindIII-EcoRI fragment containing the } B \text {. } \\
\text { subtilis Orf } 4 \text { promoter cloned in pAMB22 }\end{array}$ & Holmberg et al. (1990) \\
\hline pHPSK & $\begin{array}{l}301 \text { bp PvuII fragment of pHP13 exchanged for } 448 \text { bp } \\
\text { PvuII fragment of pFiluescript II SK }(-)\end{array}$ & This study \\
\hline pHEMX513 & B. subtilis hem $\mathrm{X}$ in $\mathrm{pHP} 13$ & Schröder et al. (1994) \\
\hline pHEMX403 & $\begin{array}{l}259 \text { bp PstI-BamHI fragment containing the Orf } 4 \\
\text { promoter of pLUM } 403 \text { cloned in pHEMX } 513\end{array}$ & This study \\
\hline pXBRE4 & $\begin{array}{l}7.9 \mathrm{kbp} \text { Sau3A (partial) fragment from Br. brevis } \\
\text { cloned in pHB201 (BamHI); complements B. subtilis } \\
1 \text { A589 }\end{array}$ & This study \\
\hline pXBRE47 & $\begin{array}{l}3 \mathrm{kbp} \text { EcoRI fragment from pXBRE4 cloned in } \\
\text { pHB201 }\end{array}$ & This study \\
\hline pXBRE49 & $\begin{array}{l}1 \cdot 1 \mathrm{kbp} \text { EcoRI-P } v u \mathrm{I} \text { fragment (hemX) of pXBRE47 } \\
\text { cloned in pHP13 }\end{array}$ & This study \\
\hline pXBRE411 & $\begin{array}{l}296 \text { bp HindIII-EcoRI fragment containing the Orf } 4 \\
\text { promoter of pLUM } 403 \text { cloned in pXBRE } 49\end{array}$ & This study \\
\hline pXSPH1 & $\begin{array}{l}4.8 \mathrm{kbp} \mathrm{MboI} \mathrm{(partial)} \mathrm{fragment} \mathrm{from} \mathrm{B.} \mathrm{sphaericus} \\
\text { cloned in pHP13 (BamHI); complements B. subtilis } \\
1 \text { A589 and } 1 \mathrm{~A} 590\end{array}$ & This study \\
\hline pXSPH10 & $\begin{array}{l}7.5 \mathrm{kbp} \text { MboI (partial) fragment from B. sphaericus } \\
\text { cloned in pHP13 (BamHI); complements B. subtilis } \\
1 \text { A590 and KA11 }\end{array}$ & This study \\
\hline
\end{tabular}


Table 1. (cont.)

\begin{tabular}{|c|c|c|}
\hline Strain or plasmid & Genotype or relevant description & Source \\
\hline pXSTE3 & $\begin{array}{l}3.7 \mathrm{kbp} \text { Sau3A (partial) fragment from } B . \\
\text { stearothermophilus cloned in pHP13 (BamHI); } \\
\text { complements B. subtilis } 1 \text { A } 589\end{array}$ & This study \\
\hline pHMAC1 & $\begin{array}{l}6.5 \mathrm{kbp} \text { Sau3A (partial) fragment from } P . \text { macerans } \\
\text { cloned in pHP13 (BamHI); complements B. subtilis } \\
3 \mathrm{G} 18 \Delta 8\end{array}$ & This study \\
\hline pXMAC1 & $\begin{array}{l}5.3 \mathrm{kbp} \text { Sau3A (partial) fragment from } P . \text { macerans } \\
\text { cloned in pHP13 (BamHI); complements B. subtilis } \\
1 \text { A590 }\end{array}$ & This study \\
\hline pXMAC15 & $2 \cdot 8 \mathrm{kbp}$ Sall fragment from pXMAC1 cloned in pHP13 & This study \\
\hline pXMAC18 & PstI deletion derivative of $\mathrm{pXMAC1}$ & This study \\
\hline pXMAC115 & $\begin{array}{l}3 \mathrm{kbp} \text { HindIII-SalI (partial) fragment from pXMAC18 } \\
\text { cloned in pHP13 }\end{array}$ & This study \\
\hline pXMAC116 & $\begin{array}{l}3.3 \mathrm{kbp} \text { PvuII (partial) fragment from pXMAC115 } \\
\text { cloned in pACYC177 (HinclI) }\end{array}$ & This study \\
\hline pXMAC3 & $\begin{array}{l}6.2 \mathrm{kbp} \text { Sau3A (partial) fragment from } P . \text { macerans } \\
\text { cloned in pHP13 (Bam HI); complements B. subtilis } \\
1 \text { A590 }\end{array}$ & This study \\
\hline pXMAC35 & $\begin{array}{l}1700 \text { bp PstI fragment from pXMAC3 cloned in } \\
\text { pBluescript II KS }(-)\end{array}$ & This study \\
\hline pXMAC39 & $\begin{array}{l}120 \text { bp Bam HI-Pst I fragment (amplified by PCR, using } \\
\text { MAC1 and MAC2 primers) from pXMAC3 cloned in } \\
\text { pHPSK }\end{array}$ & This study \\
\hline pXMAC310 & $\begin{array}{l}2.5 \mathrm{kbp} \text { PstI (partial) fragment from pXMAC3 cloned } \\
\text { in pXMAC } 39\end{array}$ & This study \\
\hline pXMAC311 & $\begin{array}{l}2.5 \mathrm{kbp} \text { Pvull fragment from pXMAC310 cloned in } \\
\text { pACYC177 (HincII) }\end{array}$ & This study \\
\hline pXMAC350 & $\begin{array}{l}1.7 \mathrm{kp} \mathrm{BamHI}-X h o l \text { fragment from pXMAC35 cloned } \\
\text { in pHB201 }\end{array}$ & This study \\
\hline pYLN2 & $\begin{array}{l}601 \text { bp BamHI-Xhol fragment from B. subtilis } 168 \\
\text { (amplified by PCR, using YLN3.5 and YLN4 primers) } \\
\text { cloned in pBluescript II KS(-) }\end{array}$ & This study \\
\hline pYLN3 & $\begin{array}{l}\text { HindIII-BamHI fragment from pHV32 containing the } \\
\text { cat gene cloned in pYLN2 }\end{array}$ & This study \\
\hline pYLN30 & $\begin{array}{l}277 \text { bp EcoRV-HindIII fragment from B. subtilis } 168 \\
\text { (amplified by PCR, using YLN10 and YLN20 } \\
\text { primers) cloned in pYLN3 }\end{array}$ & This study \\
\hline $\mathrm{pSCW} 1$ & $\begin{array}{l}\text { E. coli cys } G \text { with the Gly224Ala mutation cloned in } \\
\text { pUC19 }\end{array}$ & Warren et al. (1994) \\
\hline $\mathrm{pSCW} 2$ & E. coli cys $G^{\mathrm{A}}$ cloned in pSCW 1 & Warren et al. (1994) \\
\hline pACYC177 1 bla & $\begin{array}{l}\text { BamHI-HinclI deletion derivative of pACYC177 } \\
\text { (removes part of the bla gene) }\end{array}$ & This study \\
\hline
\end{tabular}

\section{Table 2. Oligonucleotides}

\begin{tabular}{|ll|}
\hline Oligonucleotide & \multicolumn{1}{c|}{ Sequence $\left(\mathbf{5}^{\prime} \mathbf{- 3}^{\prime}\right)$} \\
\hline MAC1 & GGATCCAGGTGAACTTGCAATGC \\
MAC2 & GCCGCTCCATCGCTTCC \\
YLN3.5 & TACAAGCGGATCCAGT \\
YLN4 & GTGCCTCTAGATTATAC \\
YLN10 & GCATCTCGATATCCATCAGTCC \\
YLN20 & GACAAGCTTTATATCAGCTCCC \\
\hline
\end{tabular}

protein (two single-residue gaps in the aligment only; not shown). Pairwise, the HemX proteins have approximately $40 \%$ sequence identity. HemX shows sequence similarity to the CcsA protein, which is required for cytochrome $c$ biogenesis in plants (Xie $e$ t al., 1998). A B. subtilis hemX deletion strain $(3 \mathrm{G} 18 \Delta \mathrm{HemX})$ is, however, not impaired in cytochrome $c$ synthesis (our unpublished data). A tryptophan-rich sequence motif, invariant in CcsA and other cytochrome $c$ biogenesis proteins (cf. Goldman et al., 1998; Thöny-Meyer, 1997), is not conserved in the HemX proteins. 


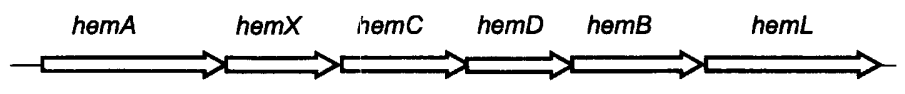

pXSTE3 (B. stearothermophilus)

pXSPH1 (B. sphaericus)

pXSPH10 (B. sphaericus)

pXBRE4 (B. brevis)

$1 \mathrm{kbL}$

Fig. 2. Physical map of chromosomal DNA fragments cloned from B. stearothermophilus, B. sphaericus and Br. brevis. The gene map shown at the top is that of $B$. subtilis and serves to illustrate the genes present on the different cloned fragments. Segments of the cloned DNA that span the hemX gene and which were sequenced continuously on both strands are indicated with thicker lines.

Table 3. Complementation of different $B$. subtilis tetrapyrrole synthesis mutants with plasmids carrying chromosomal DNA from $P$. macerans (pXMAC, pHMAC), Br. brevis (pXBRE4), B. sphaericus (pXSPH) and B. stearothermophilus (pXSTE3)

+ , Forms single colonies; - , does not form single colonies; ND, not determined.

\begin{tabular}{|c|c|c|c|c|c|c|c|}
\hline \multirow[t]{2}{*}{ Plasmid } & \multicolumn{7}{|c|}{ Complementation of B. subtilis strain: } \\
\hline & $\begin{array}{c}\text { KA11 } \\
(\text { hem } A)\end{array}$ & $\begin{array}{c}1 \mathrm{~A} 589 \\
(\text { hem B) }\end{array}$ & $\begin{array}{c}1 \mathrm{A590} \\
(\text { hem C) }\end{array}$ & $\begin{array}{c}\text { 1A591 } \\
\text { (hemD) }\end{array}$ & $\begin{array}{c}168 \Delta Y \ln F \\
(y \ln F)\end{array}$ & $\begin{array}{c}\text { LAB1926 } \\
(\text { nasF })\end{array}$ & $\begin{array}{c}3 \mathrm{G} 18 \Delta 7 \\
(\text { hemEHY) }\end{array}$ \\
\hline pXMAC1 & ND & + & + & + & ND & ND & ND \\
\hline pXMAC3 & + & ND & + & + & + & - & ND \\
\hline pXMAC15 & ND & ND & + & ND & + & ND & ND \\
\hline pXMAC115 & ND & ND & ND & + & ND & - & ND \\
\hline pHMAC1 & ND & ND & ND & ND & ND & ND & + \\
\hline pXBRE4 & ND & + & + & + & ND & ND & ND \\
\hline pXSPH1 & ND & + & + & + & ND & ND & ND \\
\hline pXSPH10 & + & ND & + & + & ND & ND & ND \\
\hline pXSTE3 & ND & + & + & + & ND & ND & ND \\
\hline
\end{tabular}

\section{Organization of hem genes in P. macerans}

An $8 \cdot 1 \mathrm{kbp}$ DNA segment containing genes for synthesis of UrollI and sirohaem from glutamyl-tRNA was cloned from $P$. macerans. Five complete open reading frames, ORF1 to ORF5, and the beginning of a sixth, ORF6, were identified in the cloned segment (Fig. 3). Located 59 bp upstream of the putative start codon of ORF1 is a typical $\sigma^{\mathrm{A}}$-type -10 promoter sequence, TATAAT. The amino acid sequence deduced from ORF1 shows $52 \%$ sequence identity to $B$. subtilis HemA (Petricek et al., 1990). pXMAC 3 complemented B. subtilis hemA, while pXMAC311 complemented E. coli hemA (Fig. 3, Table 4). (The region preceding ORF1 is not tolerated in $E$. coli.) Thus, ORF1 is hemA, encoding glutamyl-tRNA reductase.

ORF 2 shows $50 \%$ sequence similarity to the $\mathrm{N}$-terminal part of E. coli CysG (Peakman et al., 1990) (aa 1-201) (Fig. 4), an enzyme which catalyses sirohaem synthesis from UrollI (Fig. 1). The sequence similarity, together with experimental results presented in the next section, shows that ORF2 corresponds to the $\mathrm{CysG}^{\mathrm{B}}$ domain, which catalyses the conversion of precorrin- 2 into sirohaem.

P. macerans hem genes were cloned by complementation of $B$. subtilis hem $C$, indicating that bem $C$ is present in the cloned fragment. The protein encoded by ORF3 shows $59 \%$ sequence identity to B. subtilis HemC (Petricek et al., 1990), identifying ORF3 as hemC.

The N-terminal part of the protein encoded by ORF4 (aa 1-245) is similar (54\% identity) to CobA of Bacillus megaterium (Robin et al., 1991) and the C-terminal part of E. coli CysG, indicating that it functions as an $S$ adenosylmethionine-dependent UroIII methylase, i.e. it catalyses the first step in sirohaem synthesis. The Cterminal part of the ORF4 protein (aa 246-511) shows only $27 \%$ identity to the HemD protein of $B$. subtilis (Hansson et al., 1991), but expression of ORF4, on pXMAC115, was able to complement B. subtilis hemD 

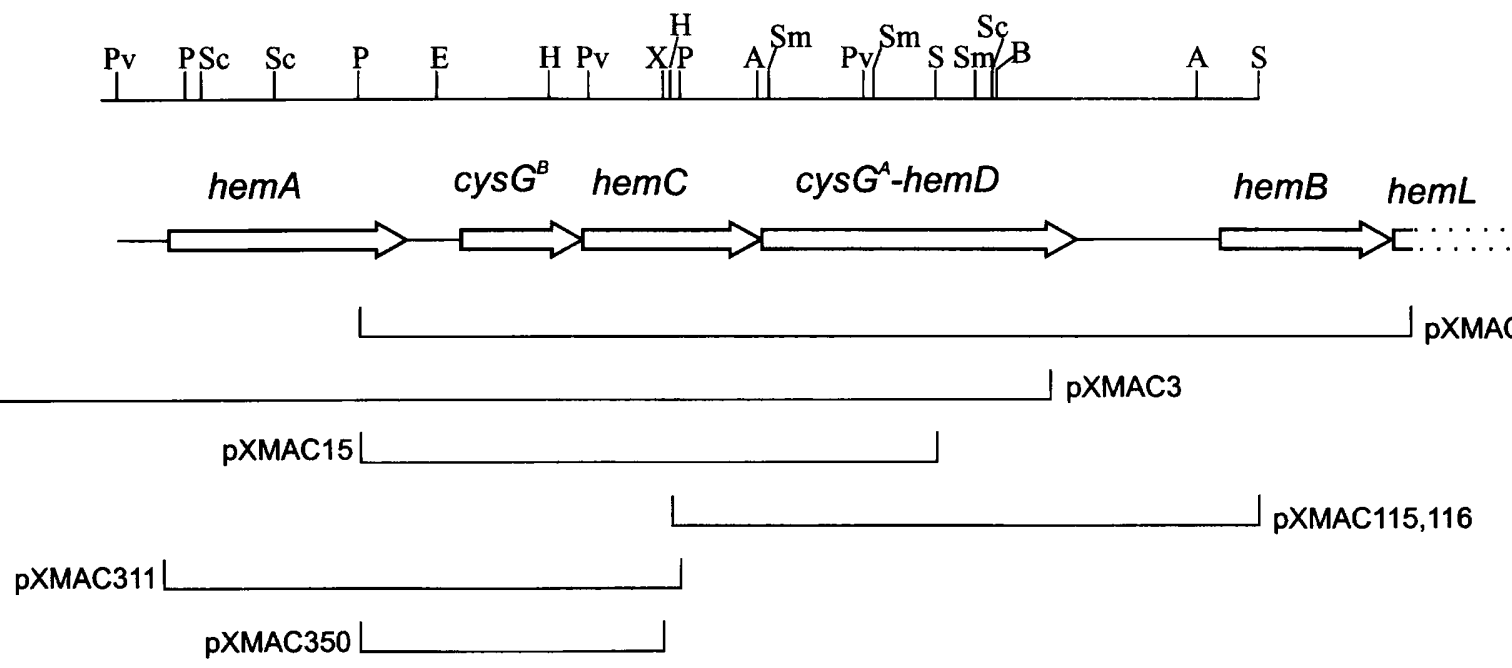

pXMAC115,116

$1 \mathrm{~kb}$

Fig. 3. Physical map of a hem gene cluster for Uroll and siroheme synthesis in P. macerans. A restriction enzyme map is provided for the part that was sequenced continuously on both strands (accession no. AF064061). Restriction site abbreviations: A, Aflll; B, BamHI; H, Hindlll; P, Pstl; Pv, Pvull; S, Sall; Sc, Scal; Sm, Smal; X, Xhol. The lines below the map indicate $P$. macerans DNA fragments cloned in the indicated plasmids.

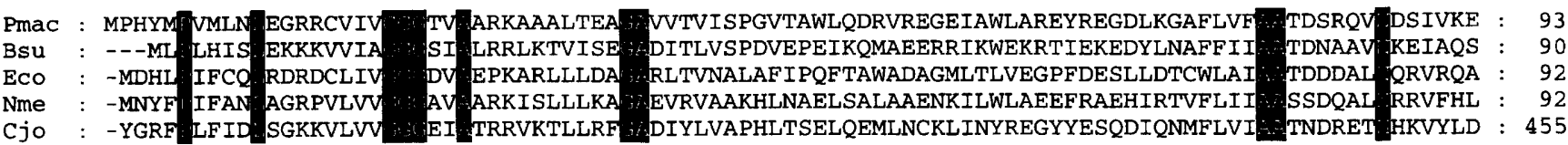

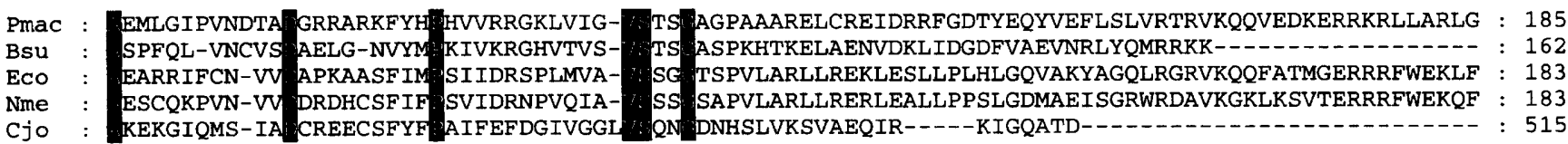

$\begin{array}{lllr}\text { Pmac : ELDILPSIRQGGFTRGANEIAAWIEEEQRRNSG- : } & 218 \\ \text { Bsu : } & \text { ECO : VNDRLAQSLANNDQK-AITETTEQLINEPLDHRG : } & 216 \\ \text { Nme : } & \text {-NGRFAALVKNRQNTLAERELAGQLEQSRQNDQG : } & 216 \\ \text { Cjo : - } & -\end{array}$

Fig. 4. Sequence alignment between $\mathrm{Cys}_{s} \mathrm{G}^{\mathrm{B}}$ proteins or domains from different bacteria. The $P$. macerans (Pmac) $\mathrm{Cys} \mathrm{G}^{\mathrm{B}}$ protein was aligned to aa 1-216 of E. coli (ECo) CysG (Peakman et al., 1990), aa 1-216 of Neisseria meningitidis (Nme) CysG (GenBank accession no. Y10177), aa 364-515 of C. josui (Cjo) HemA-CysG' (Fujino et al., 1995) and B. subtilis (Bsu) YInF (GenBank accession no. AJ000974).

and E. coli hemD (Tables 3 and 4). These findings, together with results reported in the next section, identify ORF4 as $c y s G^{\mathrm{A}}$-hemD.

The protein deduced from ORF5 shows similarity to HemB proteins from various species (Rhie et al., 1996). pXMAC1 complemented B. subtilis hemB (Fig. 3, Table 3) thus identifying ORF5 as hemB. The first part of ORF6 encodes a polypeptide which shows similarity to B. subtilis HemL.

Another $P$. macerans DNA fragment (plasmid pHMAC1) was isolated by complementation of $B$. subtilis hemH (strain $3 \mathrm{G} 18 \Delta 8$ ) and was found to also complement B. subtilis hemEHY (Table 3). This, together with partial sequence analysis of the cloned fragment, indicates that $P$. macerans contains a hemEHY operon very similar to that previously described in B. subtilis (Hansson et al., 1992).

\section{Genes for sirohaem synthesis in B. subtilis}

Sirohaem is a cofactor for assimilatory nitrite and sulphite reductases and is therefore essential for growth on nitrate or nitrite as a source of nitrogen and sulphate 
Table 4. Complementation of different $E$. coli tetrapyrrole synthesis mutants with plasmids carrying chromosomal DNA from P. macerans ( $\mathrm{PXMAC}$ ) and $E$. coli (pSCW2)

+ , Forms single colonies; -, does not form single colonies; ND, not determined.

\begin{tabular}{|c|c|c|c|c|c|}
\hline \multirow[t]{2}{*}{ Plasmid } & \multicolumn{5}{|c|}{ Complementation of $E$. coli strain: } \\
\hline & $\begin{array}{l}\text { AN344 } \\
\text { (hem } A)\end{array}$ & $\begin{array}{l}\text { SASZ31 } \\
(\text { hemD) }\end{array}$ & $\begin{array}{l}302 \Delta \mathrm{a} \\
(c y s G)\end{array}$ & $\begin{array}{c}\text { 302Aa/pXMAC116 } \\
\left(\text { cysG } G^{\mathrm{B}}\right)\end{array}$ & $\begin{array}{c}\text { 302 } \Delta \mathrm{a} / \mathrm{pSCW} 1 \\
\quad\left(c y s G^{\mathrm{A}}\right)\end{array}$ \\
\hline pXMAC116 & ND & + & - & ND & + \\
\hline pXMAC311 & + & ND & - & - & ND \\
\hline pXMAC350 & ND & ND & - & $-*$ & ND \\
\hline pSCW2 & ND & ND & + & ND & ND \\
\hline
\end{tabular}

* Cells produce a green pigment.

or sulphite as the sole sulphur source. E. coli CysG has several enzymic activities and catalyses all steps in the synthesis of sirohaem from UroIII (Warren et al., 1994). The C-terminal part of CysG, the CysG ${ }^{\mathrm{A}}$ domain, which is similar to, for example, B. megaterium CobA, catalyses $S$-adenosylmethionine-dependent methylation of UrollI to form precorrin-2, a common intermediate in sirohaem and vitamin $\mathrm{B}_{12}$ synthesis (Fig. 1). The $\mathrm{N}$ terminal part of CysG, the $\mathrm{CysG}^{\mathrm{B}}$ domain, catalyses the NAD-dependent dehydrogenation of precorrin-2 to sirohydrochlorin and the subsequent chelation with iron to form sirohaem.

The B. subtilis genome (Kunst et al., 1997) contains genes for two CysG ${ }^{\mathrm{A}}$ homologues: the $\mathrm{Y} \operatorname{lnD}$ and $\mathrm{NasF}$ proteins. UroIII methyltransferase activity of these $B$. subtilis proteins has not yet been demonstrated. $\mathrm{Y} \ln \mathrm{D}$ is of the same size as the $E$. coli CysG $^{\mathrm{A}}$ domain and $B$. megaterium CobA, while B. subtilis NasF has a Cterminal extension of 240 residues (Ogawa et al., 1995). The $y \ln D$ gene is located at $140^{\circ}$ on the chromosome together with genes encoding enzymes for sulphate reduction. The nas $F$ gene is located at $30^{\circ}$, clustered with genes encoding subunits of nitrite reductase. A NasF null mutant, LAB1926, does not grow with nitrate as a nitrogen source but can use sulphate as the only sulphur source (Ogawa et al., 1995), i.e. it apparently contains sirohaem. The phenotype of the mutant shows that a protein other than NasF, probably Y $\ln \mathrm{D}$, catalyses the $S$-adenosylmethionine-dependent methylation of UroIII in sirohaem synthesis.

The $B$. subtilis $Y \operatorname{lnF}$ protein shows $47 \%$ sequence similarity to the E. coli $\mathrm{CysG}^{\mathrm{B}}$ domain (Fig. 4) and contains in the $\mathrm{N}$-terminal part a consensus dinucleotide-binding sequence (GxGxxAxxxAxxxxxxA) which most likely is involved in binding NADH (Warren et al., 1994). The $y \ln F$ gene is located in the same gene cluster as $y \operatorname{lnD}$. A $y \ln F$ deletion mutant, strain $168 \Delta \mathrm{Y} \operatorname{lnF}$, was constructed (see Methods) in order to analyse whether or not $\mathrm{Y} \ln \mathrm{F}$ has a role in sirohaem synthesis. The mutant was unable to grow on minimal medium plates with nitrate as nitrogen source and growth was fully restored only after addition of both cysteine and ammonia to the medium. Expression of the $P$. macerans $c y s G^{\mathrm{B}}$ gene, from plasmid pXMAC3 or pXMAC15, in strain $168 \Delta$ YlnF complemented the defect (Fig. 3, Table 3). These results demonstrate that $\mathrm{Y} \ln \mathrm{F}$ in $B$. subtilis is required for sirohaem synthesis and most likely catalyses the synthesis of sirohaem from precorrin-2.

Thus, genes for sirohaem synthesis in B. subtilis seem to be clustered but are not linked to the two hem gene clusters encoding enzymes for UroIII synthesis from glutamyl-tRNA and protohaem IX synthesis from UroIII, respectively.

\section{Genes for sirohaem synthesis in P. macerans}

In contrast to $B$. subtilis, genes for sirohaem synthesis in $P$. macerans are part of the gene cluster for UroIII synthesis (Fig. 3). E. coli cys $G$ was not complemented by the $P$. macerans cys $G^{\mathrm{A}}$-hemD or cys $G^{\mathrm{B}}$ or these genes together (Table 4). However, co-expression of $c y s G^{\mathrm{A}}$. bemD and $c y s G^{\mathrm{B}}$ in the mutant resulted in the accumulation of a greenish pigment. The pigment is presumably derived from UrolII and some type of sideproduct from the sirohaem synthetic pathway. The $P$. macerans cys $G^{\mathrm{A}}$-hemD gene complemented $E$. coli cys $G^{\mathrm{A}}$, but $P$. macerans cys $G^{\mathrm{B}}$, which complemented $B$. subtilis $y \ln F$, did not complement $E$. coli $c y s G^{\mathbf{B}}$. Since the green pigment accumulated in $E$. coli only when both $P$. macerans $c y s G$ genes were present, it seems as if the $P$. macerans CysG $^{\mathbf{B}}$ protein is synthesized in E. coli but is functionally deficient. It is noted that in $E$. coli the chelatase deficiency of a $\mathrm{CysG}^{\mathrm{B}}$ mutant can be complemented by the seemingly unrelated $S$. typhimurium and B. megaterium cobalt chelatases CbiX (Raux et al., 1997; Beck et al., 1997). In these two cases, precorrin-2 is probably non-enzymically oxidized to sirohydrochlorin (Raux et al., 1997).

We conclude that $P$. macerans $c y s G^{\mathrm{A}}$-hemD encodes a protein with UroIII methylase activity while $P$. macerans cys $G^{\mathrm{B}}$ probably encodes a protein for sirohaem synthesis from precorrin-2. 
The gene organization in $P$. macerans is similar to the hem $A-c \gamma s G^{\mathrm{B}}$ hem $C$ cys $G^{\mathrm{A}}$-hemD hemB and hemA cys $G^{\mathrm{H}}$ hem $\mathrm{C} c y s \mathrm{G}^{\mathrm{A}}$-hemD heml. hemB clusters found in strictly anaerobic Clostridium species, i.e. C. josti and C. acetobutylicum (Fujino et al., 1995; pre-release by GTC, www.genomecorp.com). Perhaps it reflects the fact that $P$. macerans is a facultative anacrobe (Schirawski \& Unden, 1995).

Organization of the genes for Urolll synthesis together with those for sirohaem synthesis in one operon ensures that the enzymes for the whole pathway from glutamyltRNA to sirohaem can be co-rcgulated at the transcriptional level. This would be especially important under conditions where most or all of the Uroll produced in the cell is used for synthesis of the reduced metallo-tetrapyrroles, sirohacm and vitamin $B_{1.2}$ A cys $G^{\wedge}$-hemD gene like that of $P$. macerans and Clostridium species is found in evolutionarily very distant bacteria, e.g. in green non-sulphur bacteria (sequence data obtained through early release from The Institute for (icnomic Rescarch at www.tigr.org), cyanobacteria (Kaneko et al., 1996) and Mycobacterium (GenBank accession no. U00018). Thus, it seems as if the $c y s G^{A}$-hemD gene is of early origin in evolution and has been split into two widely separated genes in Bacillus and Staphylococcus species.

\section{ACKNOWLEDGEMENTS}

This work was supported by grants from the Swedish . Medical Research Council and the Swedish Natural Science Research Council. We are grateful to Mrs Ingrid Stáhl for technical assistance, to Dr Michiko Nakano, Dr Gottfried Unden and Dr Martin Warren for kindly providing strains and plasmids, and to Professor lars Rutberg for advice and generous support.

\section{REFERENCES}

Anderson, T. J. \& Ivánovics, G. (1967). Isolation and some characteristics of haemin dependent mutants of Bactllus subtilis. I Gen Microbiol 49, 31-40.

Ash, C., Priest, F. G. \& Collins, M. D. (1993). Molecullar identification of rRNA group 3 bacilli (Ash, Farrow, Wallhanks and Collins: using a PCR probe test. Proposal for the ercation of a new genus Paenibacillus. Antonie Lemwenhoek 64, 25.3-260.

Avissar, Y. J. \& Moberg, P. A. (1995). The common origins of the pigments of life-early steps of chlorophyll biosynthesis. Photosinth Re's 44, 221-242.

Beck, R., Raux, E., Thermes, C., Rambach, A. \& Warren, M. (1997). CbiX: a novel metal-binding protein involved in sirohaem biostuthesis in Bacillus megaterium. Biochem Soc Trans 25, 77S.

Blattner, F. R., Plunkett, G. I., Bloch, C. A. \& 14 other authors (1997). The complete genome sequence of Fschericha colt K12. Sicnie 277, 1453-1474.

Chang, A. C. \& Cohen, S. N. (1978). Construction and characterization of amplifiable multiconv DNA cloning vehicles derived from the P15A cryptic miniplasmid. J Bacteriol 134, 1141-11.56.

Chartrand, P., Tardif, D. \& Sasarman, A. (1979). Uroporphyrinand coproporphyrin l-accumulating mutant of Fscherichia coli K12. I Gen Microbiol 110, 61-66.
Cole, S. T., Brosch, R., Parkhill, J. \& 39 other authors (1998). Deciphering the biology of Mycobacterium tuberculosis from the complete genome sequence. Nature 393, 537-544.

Dailey, T. A., Meissner, P. \& Dailey, H. A. (1994). Expression of a cloned protoporphyrinogen oxidase. J Biol Chem 269, 813-815.

Fujino, E., Fujino, T., Karita, S., Sakka, K. \& Ohmiya, K. (1995). Cloning and sequencing of some genes responsible for porphyrin biosynthesis from the anaerobic hacternum Clostridium josui. J Bacteriol 177, 5169-517.5.

Goldman, B. S., Beck, D. L., Monika, E. M. \& Kranz, R. G. (1998). Transmembrane heme delivery systems. Proc Natl Acad Sci LSA 95, 5003-.5008.

Griffiths, L. \& Cole, J. A. (1987). Lack of redox control of the anacrobically-induced nir $B^{+}$gene of Eschertchia coli K12. Arch Microbiol 147, 364-369.

Haima, P., Bron, S. \& Venema, G. (1987). The effect of restruction on shotgun cloning and plasmid stability in Bacillus subtilis Marburg. Mol Gen Genet 209, 335-342.

Haima, P., van Sinderen, D., Bron, S. \& Venema, G. (1990). An improved heta-galactosidase alpha-complementation system for molecular cloning in Bacillts subtilis. Gene 93, 41-47.

Hansson, M. \& Hederstedt, L. (1992). Cloning and characterization of the Bucillus subtilis hemFIIY gene cluster which cncodes protoheme IX biosynthetic enzymes. J Bucteriol 174. 8081-80.93.

Hansson, M. \& Hederstedt, L. (1994). Bacsllus subtilis Hem Y is a peripheral membrane protein essential for protoheme IX synthesis which can oxidize coproporphyrinogen III and protoporphyrinogen IX. J Bacteriol 176, 5962-5970.

Hansson, M., Rutberg, L., Schröder, I. \& Hederstedt, L. (1991). The Bacillus subtilis bemAXCDBI. gene cluster, which encodes enzymes of the biosynthetic pathway from gluramate to uroporphyrinogen IIJ. J Bacteriol 173, 2590-2599.

Hansson, M., Gustafsson, M. C., Kannangara, C. G. \& Hederstedt, L. (1997). Isolated Bacillus stebtilis HemY has coproporphyrinogen III to coproporphyrin III oxidase activity. Biochem Biophys Actu 1340, 97-104.

Hashimoto, Y., Yamashita, M. \& Murooka, Y. (1997). The Propionibacterium fretdenreichit bem YHBXRI. gene cluster, which encodes enzymes and a regulator involved in the biosynthetic pathway from glutamate to protoheme. Appl Microbiol Biotechnol 47, 385-392.

Hippler, B., Homuth, G., Hoffmann, T., Hungerer, C., Schumann, W. \& Jahn. D. (1997). (haracterization of Bacillus subtulis hemN J Bacteriol 179, 7181-718.5.

Holmberg, C., Beijer, L., Rutberg, B. \& Rutberg, L. (1990). (ilyctrol catabolism in Bacillus subtilis: nucleotide sequence of the gencs encoding glycerol kinase $g / p K$ and glycerol-3-phosphate dehydrogenase glpD. J Gen Microbiol 136, 2367-2.376.

Holmgren, E., Hederstedt, L. \& Rutberg, L. (1979). Role of heme in synthesis and membranc binding of succinic dehydrogenase in Bacillus subtilis. / Bacteriol 138, 377-382.

Ish-Horowicz, D. \& Burke, J. F. (1981). Rapid and efficient cosmid cloning. Nucleic Acids Res 9, 2989-2998.

Kafala, B. \& Sasarman, A. (1997). Isolation of the Staphylococcus aureus hem CDBI. gene cluster coding for carly steps in heme biosynthesis. Gene' 199, 231-239.

Kaneko, T., Sato, S., Kotani, H. \& 21 other authors (1996). Sequence analysis of the genome of the unicellular cyanobacterium Synechocystis sp. strain PC(6803. II. Sequence determination of the enture genome and assignment of porential protein-coding regions. DNA Res 3, 109-136. 
Kunst, F., Ogasawara, N., Moszer, I. \& 148 other authors (1997). The complete genome sequence of the gram-positive bacterium Bacillus subtilis. Nature 390, 249-256.

MacGregor, C. H. (1976). Biosynthesis of membrane-bound nitrate reductase in Escherichia coli: evidence for a soluble precursor. J Bacteriol 126, 122-131.

Marmur, J. (1961). A procedure for the isolation of deoxyribonucleic acid from bacteria. J Mol Biol 3, 208-218.

Neville, D. M., Jr (1971). Molecular weight determination of protein-dodecyl sulfate complexes by gel electrophoresis in a discontinuous buffer system. J Biol Chem 246, 6328-6334.

Niaudet, B., Goze, A. \& Ehrlich, S. D. (1982). Insertional mutagenesis in Bacillus subtilis: mechanism and use in gene cloning. Gene 19, 277-284.

Ogawa, K., Akagawa, E., Yamane, K., Sun, Z. W., LaCelle, M., Zuber, P. \& Nakano, M. M. (1995). The nasB operon and nas $A$ gene are required for nitrate/nitrite assimilation in Bacillus subtilis. J Bacteriol 177, 1409-1413.

Peakman, T., Crouzet, J., Mayaux, J. F., Busby, S., Mohan, S., Harborne, N., Wootton, J., Nicolson, R. \& Cole, J. (1990). Nucleotide sequence, organisation and structural analysis of the products of genes in the nirB-cysG region of the Escherichia coli K12 chromosome. Eur J Biochem 191, 315-323.

Petricek, M., Rutberg, L., Schröder, I. \& Hederstedt, L. (1990). Cloning and characterization of the bemA region of the Bacillus subtilis chromosome. J Bacteriol 172, 2250-2258.

Raux, E., Thermes, C., Heathcote, P., Rambach, A. \& Warren, M. J. (1997). A role for Salmonella typhimurium cbiK in cobalamin (vitamin B12) and siroheme biosynthesis. J Bacterioi 179, 3202-3212.

Rhie, G., Avissar, Y. J. \& Beale, S. I. (1996). Structure and expression of the Chlorobium vibrioforme hemB gene and characterization of its encoded enzyme, porphobilinogen synthase. J Biol Chem 271, 8176-8182.

Robin, C., Blanche, F., Cauchois, L., Cameron, B., Couder, M. \& Crouzet, J. (1991). Primary structure, expression in Escherichia coli, and properties of $S$-adenosyl-L-methionine:uroporphyrinogen III methyltransferase from Bacillus megaterium. J Bacteriol 173, 4893-4896.
Sambrook, J., Fritsch, E. F. \& Maniatis, T. (1989). Molecular Cloning: a Laboratory Manual, 2nd edn. Cold Spring Harbor NY: Cold Spring Harbor Laboratory.

Schirawski, J. \& Unden, G. (1995). Anaerobic respiration of Bacillus macerans with fumarate, TMAO, nitrate and nitrite and regulation of the pathways by oxygen and nitrate. Arch Microbiol $163,148-154$.

Schröder, I., Johansson, P., Rutberg, L. \& Hederstedt, L. (1994). The bemX gene of the Bacillus subtilis hem $A X C D B L$ operon encodes a membrane protein, negatively affecting the steady-state cellular concentration of HemA (glutamyl-tRNA reductase). Microbiology 140, 731-740.

Shida, O., Takagi, H., Kadowaki, K. \& Komagata, K. (1996). Proposal for two new genera, Brevibacillus gen. nov. and Aneurinibacillus gen. nov. Int J Syst Bacteriol 46, 939-946.

Spizizen, J. (1958). Transformation of biochemically deficient strains of Bacillus subtilis by deoxyribonucleate. Proc Natl Acad Sci USA 82, 8129-8133.

Thöny-Meyer, L. (1997). Biogenesis of respiratory cytochromes in bacteria. Microbiol Mol Biol Rev 61, 337-376.

Towbin, H., Staehelin, T. \& Gordon, J. (1979). Electrophoretic transfer of proteins from polyacrylamide gels to nitrocellulose sheets: procedure and some applications. Proc Natl Acad Sci USA 76, 4350-4354.

Warren, M. J., Bolt, E. L., Roessner, C. A., Scott, A. I., Spencer, J. B. \& Woodcock, S. C. (1994). Gene dissection demonstrates that the Escherichia coli cys $G$ gene encodes a multifunctional protein. Biochem J 302, 837-844.

Xie, Z., Culler, D., Dreyfuss, B. W., Kuras, R., Wollman, F. A., Girard-Bascou, J. \& Merchant, S. (1998). Genetic analysis of chloroplast $c$-type cytochrome assembly in Chlamydomonas reinhardtii: one chloroplast locus and at least four nuclear loci are required for heme attachment. Genetics 148, 681-692.

Yanisch-Perron, C., Vieira, J. \& Messing, J. (1985). Improved M13 phage cloning vectors and host strains: nucleotide sequences of the M13mp18 and pUC19 vectors. Gene 33, 103-119.

Received 18 May 1998; revised 30 September 1998; accepted 13 November 1998. 